\title{
Empirical Analysis of Factors Influencing Residential Property Prices in Malaysia
}

\author{
Nazaria Md. Aris, Dickson Cheah Dick Xuan, Nurul Syuhada bt Zaidi, \\ and Suzila bt Mohamed Yusof \\ Faculty of Economics and Business, Universiti Malaysia Sarawak (UNIMAS)
}

\begin{abstract}
This study concerns the factors influencing the prices for residential properties in Malaysia as well as their relationship towards residential property prices. The data collected and analysed in this research is from quarter one year 2000 to quarter four year 2015. Various determinants have been identified namely country population, Gross Domestic Product, household income, inflation and lending rates in this research. The time-series analysis methodologies adopted in this research are the Augmented Dickey-Fuller (ADF) and Philip-Perron (PP) test for unit root, Johansen and Juselius Cointegration Test, Granger Causality Test for Vector Error Correction Model (VECM) and also Variance Decomposition (VDC). In this study, these two variables, population growth (POPGROWTH) and inflation measured by the consumer price index (CPI) were found has a significant and positive effect towards the price of residential properties in Malaysia.
\end{abstract}

Keywords: Residential Property Prices, Population, GDP, Household Income, Inflation, Lending Rates

\section{INTRODUCTION}

In the recent years, the issue of home ownership rates as well as the issue of affordability for residential houses are closely related to the movement of the house price. The phenomena of rising number of populations in Malaysia raises the issue of availability of housing since the more the people, the more the need for housing to live. The growing population is most likely to be obstructed if the housing supply does not adjust itself to the demand for housing by households. As mentioned by Vermeulen and Van Ommeran (2006), houses are constructed in places that are people may not want to live in while on the other hand, people are willing to live in places where houses are constructed. The rising property prices especially for residential housing can be explained by the statement above from the researchers when the certain states in Malaysia have higher average property prices while certain states have a lower property prices as compared.

This research is organized into various parts. The analysis of the factors influencing residential property prices in Malaysia serves as the main purpose of this research. In this study, the residential housing prices is focusing only on the prices of the main classification of the residential housing namely the terraced house, semi-detached house, detached house and also the high-rise unit. In the next section is a review of the relevant literature, where the relationship of the residential housing prices with its determinants which are the interest rates, inflation rates, number of populations and the gross domestic product (GDP) of the country are discussed. This is followed by the methodology where hypotheses are introduced and this paper concludes with a discussion of the results.

\section{LITERATURE REVIEW}

In the research conducted by Hui (2013) aimed to analyse the relationship that exists between the house prices and the macroeconomic variables for the case of Malaysia. The author used various variables that include private consumptions, gross investments, stock price, money stock, interest rates and bilateral exchange rates in order to explain the movement of house prices from quarter one in year 1991 till the quarter two in year 2006 in Malaysia. All the variables are in real terms after adjusted for inflation and are regressed through time series analysis in determining the characteristics 
of lead-lag as well as determining the relationship of the property prices and the economy's fluctuation. Shocks occurred in several variables have effects on the housing price. The gross domestic product, investment and the stock price suffered from shocks but they did not affect the house prices much. Moreover, shocks experienced by exchange rates is found to be negatively affecting the house prices since exchange rates are applied by various house investors to allow them to determine the strength of the economy of the country. As mentioned by the author, this factor is contributing to the investor's trading decision for their assets that varies during different state of the economy. Money supply is also found that have a relatively strong effect towards house prices through the results suggested by the Granger-Causality test where the two variables Granger case each other. The result is explained by the author that the money stock, M3 is utilized by investors for their investment activity especially during their forecast for the future of the housing industry. The author suggested policies for the authorities to focus on the exchange rates since its contributed significant relationships towards the house prices. The efforts by the authority need to be stressed so as to stabilize the country's property market. Ong (2013) conducted the research in determining the relationship between the determinants of house prices showed the link between the variables and the housing price in Malaysia.

The author included determinants from the macroeconomic perspective that are GDP, labour force, interest rate, inflation, Real Property Gain Tax (RPGT) and population. Conducting investigations on the economic variables using multiple regression method gives useful empirical contents to policymakers in formulating regulations and policies in the country to address the issue of housing affordability. The researcher found out that the determinants, GDP and country population are positively and significantly influencing the price of the houses. The author mentioned that when there are investments in housing explained by household consumption, it contributed to the rise of the country's GDP whereby the GDP is used to explain the growth of the macro economy. In addition, RPGT is negatively associated and statistically significant towards house price while it is found that there is an absence of the correlation between interest rates and house prices. RPGT imposed by the Malaysian government is 5\%. Purchasing houses are considered to be an investment activity further leading to the issue of speculation. The author mentioned that speculators and high-income individuals neglected the re imposition of RPGT since profit can still be gained through selling of purchased properties. The classification of housing as a normal good explained the fact that homebuyers might neglect the variation of interest rates of mortgages. The author suggested that various other determinants that have possibilities in affecting the price of houses which became our motivation of study.

\section{METHODOLOGY}

The aim of this study is to investigate the relationship between the determinants of house price, namely interest rates, gross domestic product, population growth, household income, inflation and lending rate on the effect of the residential housing prices in Malaysia.

\section{Data Analysis}

The tests included in the research were the unit root test which comprises of the Augmented Dickey Fuller (ADF) and Philip-Perron (PP), the cointegration test, vector error correction model and dynamic modelling.

\section{Augmented Dickey-Fuller (ADF) Test}

Since the research is a time series analysis, ADF test is adopted for testing the order of the integration between all the variables. The Augmented Dickey-Fuller (ADF) test is based on the auxiliary regression as follow:

$$
\Delta \mathrm{y}_{\mathrm{t}}=\delta 0+\delta 1 \mathrm{t}+\delta 2 \mathrm{y}_{\mathrm{t}-1}+\alpha \mathrm{i} \Delta \mathrm{y}_{\mathrm{t}-1}+\varepsilon_{\mathrm{t}}
$$


where $\varepsilon_{t}$ will be the error term adjusted for serial correlation and $t$ is the trend. The ADF regression is above used to test the presence of unit root in $\mathrm{y}_{\mathrm{t}} \mathrm{y}_{\mathrm{t}}$ is the variables of the model at time $t$ representing by the logarithm value while $\mathrm{y}_{\mathrm{t}-1}$ is the lag in the first difference, $\delta$.

\section{Phillips and Perron (PP) Test}

Phillips and Perron test is popularly used for examining the unit root of the series. In the test, the PP test is used were it ignores serial correlation. PP test presents a better power if it is compared to the $\mathrm{ADF}$ test results where the model of the regression for the PP test is as follow:

$$
\chi_{t}=\mu+\beta X_{t-1}+\mu_{t}^{12}
$$

where the $\mu_{\mathrm{t}}$ represents $1,2, \ldots \ldots, \mathrm{T}$ which is the innovation term.

\section{Cointegration Test}

The cointegration approach is adopted to test the presence of the long run relationship among all of the variables. The test result is that when the long-run relationship exists, it is therefore to be concluded that the variables are moving in the same trend mutually. On the other hand, when the variables are showing a movement in a different direction, the test results indicated that the long-run relationship does not exist among the variables. The cointegration long-run equation is derived as:

$$
\triangle \mathrm{Z}_{\mathrm{t}}=\Pi \mathrm{Z}_{1}+\sum_{i=1}^{k-1} \Pi_{\mathrm{i}} \triangle \mathrm{Z}_{\mathrm{t}-1}+\mu_{\mathrm{t}+} \varepsilon_{\mathrm{t}}
$$

For the variables that has one unit root, $I(1), \mathrm{Z}_{1}$ indicates the $(\mathrm{nx} 1)$ vector. Moreover, the $\Pi$ and the $\Pi_{i}$ is the ( $\left.\mathrm{n} \times \mathrm{n}\right)$ coefficient matrixes and the ( $\left.\mathrm{n} \times 1\right)$ is the constant vector when $\mathrm{i}=1, \ldots, \mathrm{k}-1 . \triangle$ is the difference operator with the $\mathrm{k}$ as the length and the $\mathrm{t}$ as the normally distributed, independent covariance matrix. This factor is adopted for the adjustment for trace and max eigen statistics because it was found by the previous researchers that the adjustment yielded better results.

$$
\frac{\mathrm{T}-(\mathbf{p k})}{\mathrm{T}}
$$

\section{Johansen and Juselius Cointegration Test}

\section{Trace Test}

Trace test is one of the likelihood ratio test to examine the cointegration that exists between the variables and the equation for the trace test is as follow:

$$
\lambda_{\text {trace }}=-\mathrm{T} \sum_{i=q+1}^{p} \operatorname{Ln}\left(1-\lambda_{\mathrm{i}}\right)
$$

The number of observation used for the estimation is indicated by ' $\mathrm{T}$ ' while ' $\mathrm{p}$ ' stands for the number of variables. $i^{\text {th }}$ is the largest estimated eigenvalue indicated by $\lambda_{\mathrm{i}}$. In the trace test, these hypotheses as formulated and stated as follow:

$\mathrm{H}_{0}: \mathrm{r}=0$ (There is an absence of cointegrating vector)

$\mathrm{H}_{\mathrm{a}}: \beta<1$ (There is a presence of cointegrating vector)

Maximum Eigenvalue Test

$$
\lambda_{\text {maximum }}=-\mathrm{T} \operatorname{Ln}\left(1-\lambda_{\mathrm{r}+1}\right)
$$

Where the hypotheses for the maximum eigenvalue test are formulated showed as follow:

$$
\mathrm{H}_{0} \text { : } \mathrm{r} \text { cointegrating vectors }
$$


$\mathrm{H}_{\mathrm{a}}: \mathrm{r}+1$ cointegrating vectors

\section{Granger Causality Test based on Vector Autoregressive Model (VAR) and Vector Error Correction Model (VECM)}

Before the Granger causality test is conducted, the variables are assumed to be stationary and there is no relationship between the stochastic terms of the model, in other words, uncorrelated. The selection of the number of lagged terms in the causality test is decided base on the Akaike or Schwarz information criterion. The standard equation for Granger causality when the variables are not cointegrated is as follow:

$$
\begin{aligned}
& \triangle \mathrm{Y}_{\mathrm{t}}=\sum_{i=1}^{n} \alpha_{\mathrm{i}} \triangle \mathrm{Y}_{\mathrm{t}-1}+\sum_{j=1}^{n} \beta_{\mathrm{i}} \Delta \mathrm{X}_{\mathrm{t}-\mathrm{j}}+\varepsilon_{1 \mathrm{t}} \\
& \triangle \mathrm{X}_{\mathrm{t}}=\sum_{i=1}^{n} \delta_{\mathrm{i}} \Delta \mathrm{Y}_{\mathrm{t}-1}+\sum_{j=1}^{n} \phi_{\mathrm{j}} \Delta \mathrm{X}_{\mathrm{t}-\mathrm{j}}+\varepsilon_{2 \mathrm{t}}
\end{aligned}
$$

However, if there is a presence of cointegration, the inclusion of $\mu_{\mathrm{t}-1}$ is necessary. When the coefficient $\beta_{\mathrm{i}}$ is not zero, it indicates a Granger causality of $\mathrm{X}_{\mathrm{t}}$ on $\mathrm{Y}_{\mathrm{t}}$. Simultaneously, when the coefficient $\delta_{\mathrm{i}}$ is not zero, it indicates a Granger causality of $Y_{t}$ on $X_{t}$. In addition, should both of the events occur, it indicates that there is presence of a bilateral causality. The general equation is indicated as follow:

$$
\triangle \mathrm{Y}_{\mathrm{t}}=\mathrm{b}_{1} \triangle \mathrm{X}_{\mathrm{t}}+\mathrm{b}_{2} \mu_{\mathrm{t}-1}+\varepsilon_{\mathrm{t}}
$$

where $\mu_{t-1}$ is the lagged value for the residuals of one period and the $\varepsilon_{t}$ represents the error term. When the variables tested shows the result of cointegration, the ECT, $\mu_{\mathrm{t}-1}$, is the speed of adjustment that interprets the changes in $\mathrm{Y}_{\mathrm{t}}$.

The equations below show the first difference in the vector autoregressive (VAR) model:

$$
\begin{aligned}
& \triangle \mathrm{Y}_{\mathrm{t}}=\gamma_{\mathrm{y}} \mu_{\mathrm{t}-1}+\sum_{i=1}^{n} \alpha_{\mathrm{i}} \Delta \mathrm{Y}_{\mathrm{t}-1}+\sum_{j=1}^{n} \beta_{\mathrm{i}} \Delta \mathrm{X}_{\mathrm{t}-\mathrm{j}}+\varepsilon_{\mathrm{lt}}
\end{aligned}
$$

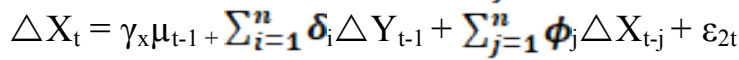

When $\gamma_{\mathrm{y}}$ and $\gamma_{\mathrm{x}}$ are zero, the VAR model is in first difference. However, if the value of $\gamma_{\mathrm{y}}$ is not zero, it means that the $\triangle \mathrm{Y}_{\mathrm{t}}$ is indicating a deviation from the equilibrium of the long run from the previous period. Thus, there is no meaning in making estimations on the value of $Y_{t}$ as a VAR in first differences if it has error correction representation. Consequently, the conclusion is that when the variables have a same order of cointegration, the VECM is used for the estimation. By using the VECM, the problem of misspecification is able to be bypassed, further indicating the Granger causality is a long run or a short run.

\section{Dynamic Analysis}

Dynamic analysis comprises of the variance decomposition (VDC). This methodology is conducted in order to identify the most endogenous as well as the most exogenous variables in this study which affects the residential property prices in Malaysia. The movement of each of the variable caused by the other variables are to be predicted and forecasted when dynamic analysis is conducted in this research.

\section{RESULTS AND FINDINGS}

\section{Unit Root Test}

The first analysis of data is the unit root test which comprises of the Augmented Dickey Fuller (ADF) unit root test and the Philip-Perron (PP) unit root test are conducted in order to identify the order of 
integration of the variables in this research as well as to ensure that the time-series variables stationary. The results obtained from both tests are demonstrated in the table as follows:

Table 1: Result of Augmented Dickey Fuller (ADF) Unit Root Test

\begin{tabular}{llccc}
\hline Variables & \multicolumn{2}{c}{ Level } & \multicolumn{2}{c}{$1^{\text {st }}$ Difference } \\
\cline { 2 - 5 } & \multicolumn{1}{c}{ Intercept } & $\begin{array}{c}\text { Trend and } \\
\text { Intercept }\end{array}$ & Intercept & $\begin{array}{c}\text { Trend and } \\
\text { Intercept }\end{array}$ \\
\hline LHPI & $3.321(0)$ & $-0.526(0)$ & $-3.764(1)^{* * *}$ & $-7.711(0)^{* * *}$ \\
LBLR & $-1.886(0)$ & $-1.995(0)$ & $-5.876(0)^{* * *}$ & $-5.892(0)^{* * *}$ \\
LCPI & $0.611(0)$ & $-2.868(0)$ & $-6.852(0)^{* * *}$ & $-6.853(0)^{* * *}$ \\
POPGROWTH & $-1.923(0)$ & $-2.939(0)$ & $-9.615(0)^{* * *}$ & $-9.914(0)^{* * *}$ \\
LINCOME & $0.871(0)$ & $-1.864(0)$ & $-10.129(0)^{* * *}$ & $-10.413(0)^{* * *}$ \\
LGDP & $-0.195(0)$ & $-1.265(0)$ & $-9.827(1)^{* * *}$ & $-9.738(1)^{* * *}$ \\
\hline
\end{tabular}

Note: $\overline{L H P I=\text { natural logarithm of house price index, } L B L R=\text { natural logarithm of base lending rate, }}$ $L C P I=$ natural logarithm of consumer price index, $P O P G R O W T H=$ population growth, LINCOME= natural logarithm of household income, $L G D P=$ natural logarithm of gross domestic product. Asterisk (*) indicates significant at 10 percent level of significance. Asterisk (**) indicates significant at 5 percent level of significance. Asterisk (***) indicates significant at 1 percent level of significance. The lag selection criteria are based on Schwarz Info Criterion. Figures in parentheses are lag lengths.

Table 2: Result of Philip-Perron (PP) Unit Root Test

\begin{tabular}{|c|c|c|c|c|}
\hline \multirow[t]{2}{*}{ Variables } & \multicolumn{2}{|c|}{ Level } & \multicolumn{2}{|c|}{$1^{\text {st }}$ Difference } \\
\hline & Intercept & $\begin{array}{l}\text { Trend and } \\
\text { Intercept }\end{array}$ & Intercept & $\begin{array}{c}\text { Trend and } \\
\text { Intercept }\end{array}$ \\
\hline LHPI & $3.281(2)$ & $-0.528(2)$ & $-6.535(4) * * *$ & $-7.729(3)^{* * *}$ \\
\hline LBLR & $-2.346(3)$ & $-2.396(3)$ & $-5.876(1)^{* * *}$ & $-5.894(1)^{* * *}$ \\
\hline LCPI & $0.932(7)$ & $-2.947(3)$ & $-6.996(8) * * *$ & $-7.052(8) * * *$ \\
\hline POPGROWTH & $-2.385(2)$ & $-2.760(2)$ & $-10.138(2)^{* * *}$ & $-10.891(2)^{* * *}$ \\
\hline LINCOME & $3.802(3)$ & $-1.020(3)$ & $-13.240(3)^{* * *}$ & $-18.558(3)^{* * *}$ \\
\hline LGDP & $-0.258(3)$ & $-2.158(3)$ & $-3.305(3)^{* *}$ & $-3.289(3)^{*}$ \\
\hline
\end{tabular}

Note: Asterisk (*) indicates significant at 10 percent level of significance. Asterisk (**) indicates significant at 5 percent level of significance. Asterisk $\left(^{* * *}\right)$ indicates significant at 1 percent level of significance. The lag selection criteria are based on Newey-West Bandwidth. Figures in parentheses are lag lengths.

The set of hypotheses for Philip-Perron (PP) unit root test is identical to the hypotheses for Augmented Dickey Fuller (ADF) unit root test. In a nutshell, according to the test results obtained from the Augmented Dickey Fuller (ADF) and Philip-Perron (PP) unit root test, all the variables namely LHPI, LBLR, LCPI, POPGROWTH, LINCOME, LGDP are stationary at first difference form of both intercept and trend intercept.

\section{Johansen and Juselius Cointegration Test}

Table 3 below shows the results obtained from the Johansen and Juselius Cointegration test. ' $\mathrm{k}$ ' represents the lag length for the test, which in the case is 3 whereas ' $r$ ' represents the number of cointegrating vector which is 1 . 
Table 3: Result of Johansen and Juselius Cointegration Test

\begin{tabular}{|c|c|c|c|c|c|c|c|}
\hline \multirow{3}{*}{ Null } & \multirow{3}{*}{ Alternative } & \multicolumn{3}{|c|}{ Trace } & \multicolumn{3}{|c|}{ Max Eigenvalue } \\
\hline & & Unadjusted & Adjusted & $99 \%$ & Unadjusted & Adjusted & $99 \%$ \\
\hline & & & & C.V. & & & C.V. \\
\hline \multicolumn{8}{|c|}{$\mathrm{k}=3, \mathrm{r}=1$} \\
\hline $\mathrm{r}=0$ & $\mathrm{r}=1$ & 164.934 & $\begin{array}{c}118.546 \\
*\end{array}$ & 104.962 & 68.040 & 48.903* & 45.869 \\
\hline $\mathrm{r} \leq 1$ & $\mathrm{r}=2$ & 96.895 & 69.643 & 77.819 & 43.759 & 31.452 & 39.370 \\
\hline$r \leq 2$ & $r=3$ & 53.136 & 38.191 & 54.682 & 26.815 & 19.273 & 32.715 \\
\hline$r \leq 3$ & $\mathrm{r}=4$ & 26.321 & 18.982 & 35.458 & 21.065 & 15.140 & 25.861 \\
\hline$r \leq 4$ & $r=5$ & 5.256 & 3.778 & 19.937 & 5.245 & 3.770 & 18.520 \\
\hline$r \leq 5$ & $r=6$ & 0.011 & 0.008 & 6.635 & 0.011 & 0.079 & 6.635 \\
\hline
\end{tabular}

Note: The lag length is $k$ and the cointegrating vector is $r$, which is significant under Trace test and Maximum Eigenvalue. Asterisk (*) represents statistically significant at 1 percent level of significance.

The interpretation for the Maximum Eigenvalue test is similar with the Trace test. Therefore, the null hypothesis is also rejected. In conclusion, there is only one cointegrating vector at 1 percent level of significance. In other words, all of the variables in this research, namely LHPI, LBLR, LCPI, POPGROWTH, LINCOME and LGDP have a long run relationship among them.

\section{Normalized Cointegrating Vector Estimates}

From the previous results obtained from the cointegation test, it is confirmed that there is only one long run relationship among all of the variables. The cointegration test confirmed the following test which will be reported in this section which is the Vector Error Correction Model (VECM). The result for the estimation is obtained in an equation form as below:

$$
\begin{aligned}
& \text { LHPI }=-2.290+0.999 \text { POPGROWTH }-0.854 \text { LGDP }-0.294 \text { LINCOME }+2.153 \text { LCPI }-0.160 \text { LBLR } \\
& \begin{array}{lllll}
(14.071) \quad(-5.641) & (-8.242) & (7.476) & (-2.318)
\end{array}
\end{aligned}
$$

The t-statistics for each variable in the estimated equation were showed in the parenthesis and they are compared with the critical value of 5 percent level of significance to test for its significance in the estimated equation. The set of hypotheses to test for significance is as below:

$$
\begin{gathered}
\mathrm{H}_{0} \text { : The variable is insignificant } \\
\mathrm{H}_{1} \text { : The variable is significant }
\end{gathered}
$$

From the equation, it is noticed that the variable, POPGROWTH indicating population growth has a positive sign. The coefficient of population growth indicates that when there is 1 percent increase in population growth, there is 0.999 percent increase in residential house prices. LCPI represents the natural logarithm for consumer price index, a variable measuring inflation shows a positive relationship with house price index. From the estimation result, when there is a 1 percent increase in consumer price index, there is an increase of 2.153 percent in house price index. It is in line with majority of the studies that inflation in the country do contribute to the rise of the residential property prices.

\section{Granger Causality Test for VECM}

Johansen and Juselius Cointegration test determined that there is only one cointegrating vector and only one error correction term (ECT). This allows the Vector Error Correction Model (VECM) to be 
used in this research. The result for the Vector Error Correction Model (VECM) Granger-Causality test is shown in Table 4.4 below.

Table 4: Result for VECM Granger-Causality

\begin{tabular}{|c|c|c|c|c|c|c|c|c|}
\hline \multirow[t]{2}{*}{ Variables } & $\Delta$ LHPI & $\triangle$ POPGR & $\Delta \mathbf{L G D P}$ & $\Delta \mathbf{L C P I}$ & $\Delta \mathbf{L B L R}$ & $\triangle$ LINCOME & \multicolumn{2}{|c|}{ ECT } \\
\hline & \multicolumn{6}{|c|}{$\chi^{2}$-Statistics } & Coefficients & t-stat \\
\hline$\Delta$ LHPI & - & $\begin{array}{l}7.745 \\
(0.052)\end{array}$ & $\begin{array}{l}0.182 \\
(0.981)\end{array}$ & $\begin{array}{l}0.583 \\
(0.900)\end{array}$ & $\begin{array}{l}2.767 \\
(0.429)\end{array}$ & $\begin{array}{l}21.620 \\
(0.000)^{* *}\end{array}$ & -0.032 & -1.456 \\
\hline $\begin{array}{l}\triangle \text { POPGR } \\
\text { OWTH }\end{array}$ & $\begin{array}{l}2.417 \\
(0.491)\end{array}$ & - & $\begin{array}{l}0.209 \\
(0.976)\end{array}$ & $\begin{array}{l}1.149 \\
(0.765)\end{array}$ & $\begin{array}{l}4.929 \\
(0.177)\end{array}$ & $\begin{array}{l}6.846 \\
(0.077)\end{array}$ & -0.273 & -12.241 \\
\hline$\Delta$ LGDP & $\begin{array}{l}1.641 \\
(0.650)\end{array}$ & $\begin{array}{l}9.486 \\
(0.024)^{* *}\end{array}$ & - & $\begin{array}{l}2.437 \\
(0.487)\end{array}$ & $\begin{array}{l}5.427 \\
(0.143)\end{array}$ & $\begin{array}{l}1.070 \\
(0.784)\end{array}$ & -0.003 & -1.648 \\
\hline$\Delta \mathbf{L C P I}$ & $\begin{array}{l}3.357 \\
(0.340)\end{array}$ & $\begin{array}{l}0.689 \\
(0.196)\end{array}$ & $\begin{array}{l}17.668 \\
(0.001)^{* *}\end{array}$ & - & $\begin{array}{l}21.862 \\
(0.000)^{* *}\end{array}$ & $\begin{array}{l}0.821 \\
(0.844)\end{array}$ & -0.016 & -0.960 \\
\hline$\triangle \mathbf{L B L R}$ & $\begin{array}{l}0.926 \\
(0.819)\end{array}$ & $\begin{array}{l}2.169 \\
(0.538)\end{array}$ & $\begin{array}{l}8.508 \\
(0.037)^{* *}\end{array}$ & $\begin{array}{l}1.311 \\
(0.727)\end{array}$ & - & $\begin{array}{l}1.556 \\
(0.669)\end{array}$ & -0.006 & -0.120 \\
\hline $\begin{array}{l}\triangle \mathrm{LINCO} \\
\mathrm{ME}\end{array}$ & $\begin{array}{l}7.091 \\
(0.069)\end{array}$ & $\begin{array}{l}39.545 \\
(0.000)^{* *}\end{array}$ & $\begin{array}{l}0.065 \\
(0.996)\end{array}$ & $\begin{array}{l}1.390 \\
(0.708)\end{array}$ & $\begin{array}{l}5.091 \\
(0.165)\end{array}$ & - & 0.134 & 4.642 \\
\hline
\end{tabular}

Note: Value in parenthesis () indicates the probability value (p-value). The asterisk (*) indicates significant at 5 percent level of significant.

There are six interrelationships among all of the variables in the short run. The variable population growth Granger cause gross domestic product as well as household income. For instance, it is confirmed when its respective p-value is less than 5 percent level of significance. Besides, it is found out that the variable, gross domestic product Granger cause consumer price index and base lending rate. Consumer price index is Granger caused by base lending rate whereas the household income is determined to Granger cause house price index. In short, all the relationships are in unidirectional which will be represented in a figure below.

Figure 1: Short Run Causality Direction

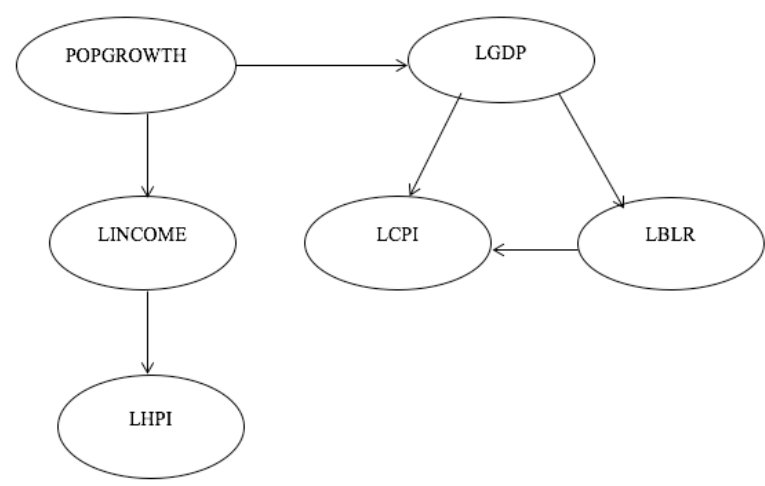

Note: POPGROWTH $\longrightarrow L G D P$ represents unidirectional causality

The result above shows the causality direction among all the variables in this research. It shows that LINCOME Granger cause LHPI whereas POPGROWTH Granger cause LINCOME. This indicates an indirect Granger causality of POPGROWTH on the LHPI. This result obtained is in in line with the previous study done by Liu and Shen (2005). Besides, the results show that POPGROWTH Granger cause LGDP and LGP Granger cause both LCPI and LBLR. In addition, it is found that LBLR Granger cause LCPI. 


\section{Variance Decomposition (VDCs)}

As a part of dynamic analyses, the test of Variance Decomposition is conducted. The test results from VDC should confirm the test results from the Granger Causality test as conducted earlier on. VDC test is carried out in order to forecast the error variance between all the variables namely, LHPI, POPGROWTH, LINCOME, LGDP, LCPI and LBLR for the next 10 quarter.

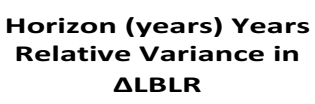

5.028
6.076
4.343
4.817
4.585
4.395
4.077
3.726
3.433
3.181

$\begin{array}{ll}0.074 & 0.249 \\ 2.491 & 1.106 \\ 8.746 & 0.705 \\ 9.773 & 1.232 \\ 9.335 & 1.877 \\ 8.814 & 2.389 \\ 8.909 & 2.714 \\ 9.104 & 2.936 \\ 9.110 & 3.054 \\ 9.101 & 2.997\end{array}$

3.203
3.776
7.378
10.141
11.544
11.764
11.172
10.233
9.274
8.464

$\begin{array}{cc}11.351 & 80.095 \\ 19.154 & 67.397 \\ 10.888 & 67.939 \\ 7.285 & 66.753 \\ 5.644 & 67.015 \\ 4.813 & 67.825 \\ 4.329 & 68.799 \\ 3.980 & 70.021 \\ 3.593 & 71.535 \\ 3.274 & 72.983\end{array}$

From the results above, it can be observed and concluded that there are exogenous and endogenous variable present in this research. The most exogenous variable is the house price index while the most endogenous variable is the population growth. House price index is said to be the most exogenous due to the fact that its influential power remains throughout the 10th quarter. Population growth is said to be the most endogenous due to the fact that its influential power loses throughout the forecasting period of the 10th quarter.

\section{CONCLUSION}

This study is conducted using the quarterly data from the year of 2000 till 2015. Most of the secondary data were retrieved from the CEIC database, Department of Statistics of Malaysia, Thomson Reuters DataStream and National Property Information Centre (NAPIC) database. The data for the variables were analysed using E-views econometric software. The tests included in the research were unit root test, dynamic modelling, vector error correction model, and cointegration test. This study was conducted to examine the effect of potential determinants on residential property prices in Malaysia. Following important conclusions, only two variables (population growth (POPGROWTH) and inflation measured by the consumer price index (CPI) were found to be positively and significantly correlated with the housing price in Malaysia. The result is not surprising due to the results obtained are in line with majority of the studies by previous researchers (Liu \& Shen, 2005; Ong, 2013; Guo \& Wu, 2013; Tse, Ho \& Ganesan, 1999). This indicates when the population of the country increases, it contributes to the rise of the residential housing price in the country. The increase in demand of home ownership by the citizen, thus cause the housing price higher. However, when inflation rate is high, it directly raises the cost of things and proportionally raises the house price. High value of house price, thus cause buyers delayed owning a house to avoid suffering with high housing loan. This study would be able to provide recommendations for policymakers to construct housing policies by referring to the results obtained and discussed in the above.

\section{REFERENCES}

Aziz, W. N. A. W. A., Hanif, N. R., \& Singaravello, K. (2011). Affordable housing within the middle income households in Malaysia: Challenge to enter homeownership. Australian, Journal of Basic and Applied Sciences, 5(8), 258-67. 
Bujang, A., Jiram, W. A., Zarin, H. A., \& Jaafar, M. N. (2015). Factor affecting the housing financing of bumiputera in Iskandar Malaysia. Journal of Economics, Business and Management, 3(11), 1031-1036.

Guo, M., \& Wu, Q. (2013). The empirical analysis of affecting factors of Shanghai housing prices. International Journal of Business and Social Science, 4(14), 218-223.

Hashim, Z. A. (2010). House price and affordability in housing in Malaysia, Akademika, 78, 37-46.

Hui, H. C. (2013). Housing price cycles and aggregate business cycles: Stylised facts in the case of Malaysia. The Journal of Developing Areas, 47(1), 149-169.

Ismail, S., Jalil, I. N., \& Muzafar, M. M. (2015). Making housing affordable. Kuala Lumpur, Malaysia: Khazanah Research Institute.

Johansen, S. (1988). Statistical analysis of cointegration vectors. Journal of economic dynamics and control, 12(2-3), 231-254.

Kang, H. H., \& Liu, S. B. (2014). The impact of the 2008 financial crisis on housing prices in China and Taiwan: A quantile regression analysis. Economic Modelling, 42, 356-362.

Nellis, J. G., \& Longbottom, J. A. (1981). An empirical analysis of the determination of house prices in the United Kingdom. Urban Studies, 18(1), 9-21.

Ong, T. S. (2013). Factors affecting the price of housing in Malaysia. Journal of Emerging Issues in Economics, Finance and Banking, 1(5), 414-429.

Pour, M. S., Khani, P. N., Zamanian, G., \& Barghandan, K. (2013). Specifying the effective determinants of house price volatilities in Iran. Economic Review: Journal of Economics \& Business/Ekonomska Revija: Casopis za Ekonomiju i Biznis, 11(2), 15-20.

Tan, T. H. (2010). Base lending rate and housing prices: Their impacts on residential housing activities in Malaysia. Journal of Global Business and Economics, 1(1), 1-14.

Xu, L., \& Tang, B. (2014). On the determinants of UK house prices. International Journal of Economics and Research, 5(2), 57-64.

Zandi, G., Mahadevan, A., Supramaniam, L., Aslam, A., \& Theng, L. K. (2015). The economical factors affecting residential property price: The case of Penang island. International Journal of Economics and Finance, 7(12), 200-210

Corresponding Author: Nazaria Md. Aris can be contacted at manazaria@unimas.my 